\title{
Article
}

\section{Using elemental profiling to determine intrinsic markers to track the dispersal of Prostephanus truncatus, a pest of stored grain with alternative natural hosts}

Tigar, Barbara and Hursthouse, Andrew S

Available at http://clok.uclan.ac.uk/15653/

Tigar, Barbara ORCID: 0000-0001-6037-3544 and Hursthouse, Andrew S (2016) Using elemental profiling to determine intrinsic markers to track the dispersal of Prostephanus truncatus, a pest of stored grain with alternative natural hosts. Entomologia Experimentalis et Applicata, 160 (1). pp. 83-90. ISSN 0013-8703

It is advisable to refer to the publisher's version if you intend to cite from the work. http://dx.doi.org/10.1111/eea.12459

For more information about UCLan's research in this area go to http://www.uclan.ac.uk/researchgroups/ and search for <name of research Group>.

For information about Research generally at UCLan please go to http://www.uclan.ac.uk/research/

All outputs in CLoK are protected by Intellectual Property Rights law, including Copyright law. Copyright, IPR and Moral Rights for the works on this site are retained by the individual authors and/or other copyright owners. Terms and conditions for use of this material are defined in the policies page. 


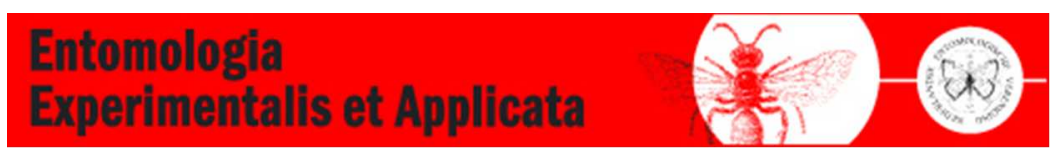

\section{Using elemental profiling to determine intrinsic markers to track the dispersal of Prostephanus truncatus, a pest of stored grain with alternative natural hosts}

\begin{tabular}{|r|l|}
\hline Journal: & Entomologia Experimentalis et Applicata \\
\hline Manuscript ID & EEA-2015-0218.R1 \\
\hline Manuscript Type: & Regular Paper \\
\hline Date Submitted by the Author: & 28 -Jan-2016 \\
\hline Complete List of Authors: & $\begin{array}{l}\text { Tigar, Barbara; Liverpool Hope University, Health Sciences } \\
\text { Hursthouse, Andrew; University of the West of Scotland, School of Science } \\
\text { \& Sport }\end{array}$ \\
\hline Key Words: & $\begin{array}{l}\text { Inductively Coupled Plasma Atomic Emission Spectroscopy, ICP-AES, } \\
\text { elemental screening, chemoprints, biomarkers, larger grain borer }\end{array}$ \\
\hline
\end{tabular}


1

2

3

4

5

6

7

8

9

10

11

12

13

14

15

16

17

18

19

20

21

22

23

24

25

26

27

28

29

30

31

32

33

34

35

36

37

38

39

40

41

42

43

44

45

46

47

48

49

50

51

52

53

54

55

56

57

58

59

60
1

3 Authors

4 Barbara J. Tigar

$5 \quad$ Andrew S. Hursthouse

6

7 Addresses

8 School of Health Sciences, Liverpool Hope University, Hope Park, Liverpool L16 9JD, UK

9 School of Science \& Sport, University of the West of Scotland, Paisley Campus, Paisley PA1

$10 \quad 2 B E, U K$

11

12 Correspondence

13 Barbara Jane Tigar

14 School of Health Sciences, Liverpool Hope University, Hope Park, Liverpool L16 9JD, UK

15 tigarb@hope.ac.uk

16

17 Short title for running headlines chemoprints, biomarkers, larger grain borer, natal origin. 
26 Detecting sources of insects attacking grain stores can help to develop more effective pest

27 management models. This study considers combinations of chemical elements as intrinsic markers

28 for tracing resource-use by Prostephanus truncatus (Horn) (Coleoptera: Bostrichidae) a pest of

29 stored maize which occurs in natural environments where alternative hosts may support reservoirs

30 of infestation.

31

32 P. truncatus were lab-reared on maize or field-caught in pheromone-baited flight-traps. Beetles and

33 hosts were screened for multiple elements using Inductively Coupled Plasma Atomic Emission

34 Spectrometry (ICP-AES). For elements above detection limits we tested relationships between

35 determinations for different host plants, and for beetles according to environment where captured.

37 An alternative host Spondias purpurea (Linnaeus) (Anacardaceae) contained more Al, B, Ca, Cu, Fe,

$38 \mathrm{Mg}$, Si and $\mathrm{Sr}$, and less $\mathrm{P}$ and $\mathrm{Zn}$ than maize. Trends for $\mathrm{P}$ were consistent between maize and beetles

39 infesting maize, but reversed for $\mathrm{Ca}$ and $\mathrm{Mg}$. Elemental profiles of beetles were associated with

40 environment, with significantly lower $\mathrm{Al}, \mathrm{Ca}, \mathrm{Cu}, \mathrm{Cr}, \mathrm{Fe}, \mathrm{P}, \mathrm{S}, \mathrm{Si}, \mathrm{Sr}, \mathrm{Ti}$ and $\mathrm{Zn}$ determinations in maize-

41 reared beetles than those captured in agricultural or natural environments. Additionally, Al, Ba, K, P,

$42 \mathrm{Sr}$ and Ti determinations of field beetles captured in agricultural vs natural environments were

43 significantly different. This suggests $\mathrm{Al}, \mathrm{Sr}$ and Ti as candidate markers for environment, plus other

44 possibilities likely since elemental concentrations (except $\mathrm{B}, \mathrm{Ba}, \mathrm{Ni}$, and $\mathrm{P}$ ) were significantly different

45 in comparisons of all field beetles vs maize-reared beetles.

47 We present a robust practical solution which successfully identified combinations of elemental

48 markers for remotely tracing resource-use and dispersal by $P$. truncatus. We discuss the application 
49 of chemical characterisation for identifying intrinsic markers of pests, particularly species with

50 alternative hosts. We discuss how to manage the low replication and unbalanced sample sizes

51 inherent in insect elemental screening, particularly when rarer elements are potential markers.

\section{Introduction}

54 Flight is the main dispersal mechanism of insect pests, with their establishment and spread dependent upon reaching suitable environments and hosts, and whilst many species are monitored for pest management purposes, their natal origin is unknown. Primary storage pests complete their

57 life cycle inside intact cereals grains where their damage goes undetected, facilitating infestation by other pests (Munro, 1940). Infestation can be reduced through good hygiene and chemical or physical control with the solid structure of stores forming a barrier to pests. However, most smallscale tropical stores are open structure experiencing temperatures conducive to insect flight and reproduction, and may suffer high levels of infestation from incoming pests (Haines, 2000).

This study uses multiple elemental profiles to identify intrinsic markers of dispersal of the larger grain borer Prostephanus truncatus (Horn)(Coleoptera: Bostrichidae). Such analytical approaches have the potential to detect the assimilated diet of organisms, including evidence of natal diets in dispersing adults, in contrast to gut content analyses which reveal recent adult diet (Borgemeister et al. 1998a). This insect is native to Mesoamerica and an introduced pest of maize and dried cassava in Africa (Hodges et al., 1983; Hodges et al., 1985). It is frequently monitored using traps baited with synthetic analogues of its aggregation pheromone (Hodges et al., 1984) and a similar pheromonetrapping system exists for the lesser grain borer, Rhyzopertha dominica (F.) (Colepotera: grain stores as well as environments far from cereal production or storage (Borgemeister et al., 
74 al., 1994). Systematic searching for $P$. truncatus around traps with high catches has rarely located

75 insects suggesting that they are sparsely distributed inside diverse plant structures such as twigs,

76 deadwood, roots and buried seeds (Nansen et al., 2004).

77 Most Bostrichidae are wood-borers requiring woody hosts (Lui et al., 2008) and the widespread

78 occurrence of two bostrichid grain pests in natural environments suggests they may not depend

79 solely upon stored grains. Evidence of $P$. truncatus' non-agricultural hosts include its occurrence in

80 cerambycid-girdled twigs of S. purpurea (Linnaeus)(Anacardaceae) and Bursera fagariodes Engler

81 (Burseraceae) in Mexican forests (Ramírez Martínez et al., 1994) and of Lannea nigritana (Sc. Elliot)

82 Keay (Anacardaceae) in African forests (Borgemeister et al., 1998b), with the effects of twig-girdling

83 thought to benefit cerambycid larvae and smaller wood-borers including $P$. truncatus (Calderón-

84 Cortés et al. 2011; Forcella, 1982). Further signs of $P$. truncatus' host-flexibility include reproduction

85 on Delonix negra (Bojer ex Hook) Raf. (Fabaceae), Acacia polyacanthus Willd (Fabaceae),

86 Commiphora rostrata Engl. (Burseraceae), Commiphora balensis Engl. (Burseraceae) and Euphorbia

87 tirucalli (Euphorbiaceae), plus boring or limited reproduction on 15 other woody species (Nang'ayo

88 et al., 2002). It has been reared on Ficus and cassava roots and has limited reproduction on teak

89 seeds, Tectona grandis Linn. F. (Lamiaceae) (Nansen et al., 2004). Whilst for R. dominica, alternative

90 hosts include acorns of native North American oaks (Jia et al., 2008) with evidence of other non-

91 grain hosts in natural habitats (Edde \& Phillips, 2006).

92 Multi-elemental loadings of biological materials are commonly used to establish origin, and nutrient

93 or contaminant levels in foods (Engström et al., 2004; Kelly et al., 2005) but rarely applied to insects,

94 although used with varying degrees of success to trace host-use and natal origin of aphids, moths

95 and weevils (Bowden et al., 1984; Bowden et al., 1985a; Bowden et al., 1985b; Burns et al., 1985;

96 Sherlock et al., 1984; Sherlock et al., 1985; 1986). More recently, Tigar \& Waldron (2003) proposed

97 using elemental profiling to identify remote markers of $P$. truncatus, and Mahroof \& Phillips (2012)

98 applied the technique to $R$. dominica and found specific elements were associated with cereal- 
1

2

3

4

5

6

consumption or agricultural environments whilst others were indicative of natural host-consumption or non-agricultural environments.

This study uses ICP-AES to produce multiple elemental profiles of $P$. truncatus with the aim of identifying patterns of elements that can distinguish between insects according to their natal host. We explore elemental profiles of maize and a natural host S. purpurea, and of $P$. truncatus reared on maize and collected in Mexico from agricultural areas where maize was present and natural vegetation far from cereal production or storage. An intrinsic method to trace resource-use and origin of stored product and other pests routinely captured in biosecurity surveillance monitoring would increase our understanding of the role of natural reservoirs as sources of infestation, and thus help inform pest management.

Materials and Methods

\section{Field and laboratory sampling}

We collected maize grains and S. purpurea branches in Mexico, and captured P. truncatus in pheromone-baited flight-traps (lures supplied by AgriSense, UK) in August, a peak period of flight activity (Tigar et al., 1994). Traps were deployed for 48 hours to sample nearby insects based on knowledge of their likely dispersal towards pheromone-baits (Helbig et al., 1992). Trapping environments included arable areas where maize was grown and natural environments far from maize production and storage, further information is given in Table 1 which characterises samples for comparison and statistical analyses.

The laboratory-bred beetles (the maize category in Table 1) were a strain of $P$. truncatus collected in Tanzania and kept in culture since the 1980s (provided by the Natural Resources Institute, University of Greenwich, Chatham, Kent, UK and held under DEFRA licence at the University of West of 
124 Scotland). Insects were kept in honey jars in an incubator at $25^{\circ} \mathrm{C} \pm 0.5^{\circ} \mathrm{C}$ and reared on Mexican

125 maize through two generations from egg to adult before extraction and analysis (repeated attempts

126 to rear $P$. truncatus on S. purpurea in the laboratory were unsuccessful). Beetles were euthanized by

127 freezing immediately after field capture or removal from laboratory cultures, and defrosted before

128 analysis.

129

130 Sample preparation and ICP-AES assays

131 All materials were rinsed in ultra-pure water and dried overnight at $40^{\circ} \mathrm{C}$ and homogenized by

132 grinding in an agate pestle and mortar. Each $P$. truncatus determination required a bulk sample of 10

133 adults (approximately $10 \mathrm{mg}$ ). Insect samples were heated in a 20 minute microwave digestion

134 programme reaching $600 \mathrm{~W}$ and the cooled digests were made up to $5 \mathrm{ml}$ with ultra-pure water. For

135 maize and S. purpurea, 0.2-0.3 g samples were mixed with $1 \mathrm{ml} \mathrm{H}_{2} \mathrm{O}_{2}$ and $3 \mathrm{ml} \mathrm{c} . \mathrm{HNO}_{3}$ in a PFM

136 digestion bomb using the same digestion program as beetles. When cooled, the digests were made

137 up to $25 \mathrm{ml}$ with ultra-pure water.

138 The digests were screened for $\mathrm{Al}, \mathrm{B}, \mathrm{Ba}, \mathrm{Ca}, \mathrm{Cr}, \mathrm{Cu}, \mathrm{Fe}, \mathrm{K}, \mathrm{Mg}, \mathrm{Mn}, \mathrm{Na}, \mathrm{Ni}, \mathrm{P}, \mathrm{S}, \mathrm{Si}, \mathrm{Sr}, \mathrm{Ti}, \mathrm{V}, \mathrm{Zn}$ and $\mathrm{Zr}$

139 in a Perkin-Elmer Optima 3000 ICP Spectrometer under default conditions (Gal et al., 2008).

140 Determinations for each analyte were means from four readings off a calibration curve, and those

141 exceeding the calibration range were diluted as required. Detection Limits (DL) were established for

142 rarer elements likely to be at low concentrations (see Table 2). We established reference samples for

143 beetles and maize which were analysed in tandem with test samples and ICP-AES elemental

144 standards for consistency of determination.

145

146 Data Analysis 
147 Multi-element loadings of $P$. truncatus were explored by classifying beetles according to site 148 characteristics and proximity to maize as described in Table 1. Firstly, we placed them into three

149 groups (maize, agriculture and natural) and compared loadings of elements between beetles in 150 these groups. Then we combined all pheromone-trapped beetles (the agriculture and natural 151 groups) into a single field class and compared their elemental loadings with those of maize-reared 152 beetles. We also identified trends in elemental loadings of maize and S. purpurea and compared 153 these with trends in P. truncatus according to environment of capture.

154 For ease of visual interpretation, elemental determinations were grouped into low and high

155 concentrations according to their relative values in insects and plant hosts. We used SYSTAT 13 with

156 Exact tests (Systat Software Inc., 2009) to handle unequal replication and any missing values for

157 determinations below detection limits (DL). The elemental data distributions were diverse with

158 many skewed towards very low concentrations. As no single transformation could produce normal

159 distributions of the data we performed non-parametric Kruskal Wallis (Mann-Whitney U) tests to

160 examine differences between groups, with post-hoc Dwass-Steel-Chritchlow-Fligner tests to identify

161 differences between pairs of groups. These make no assumptions about the normality of data

162 distributions and hence are unlikely to produce significant results when there are no real differences 163 between groups (Dytham, 2011).

164 Results

165 Elemental profiles and concentrations

166 Of the 20 elements detected Al, B, Ba, Ca, Cr, Cu, Fe, K, Mg, Mn, Na, Ni, P, S, Si, Sr, Ti, V, Zn and Zr, 167 there were 14 above $\mathrm{DL}$ in all materials tested. Those below DL were $\mathrm{Cr}, \mathrm{Ni}, \mathrm{Ti}, \mathrm{V}$ and $\mathrm{Zr}$ for maize 168 and wood, and $\mathrm{V}$ and $\mathrm{Zr}$ for $P$. truncatus. Na concentrations in living organisms are often controlled 169 by regulatory processes and are not considered further. 
171 There were differences between elemental determinations of maize and wood, and results for low

172 and high concentrations are shown in Figures 1 and 2 respectively. The $S$ determinations were

173 similar for both hosts, and apart from $\mathrm{P}$ and $\mathrm{Zn}$ which were at higher concentrations in maize than

174 wood, most elements appear to be at higher concentrations in wood than in maize, including Ba and

175 Sr which were below DLs in maize. There were significant differences for $\mathrm{Al}, \mathrm{B}, \mathrm{Ca}, \mathrm{Cu}, \mathrm{Fe}, \mathrm{Mg}, \mathrm{P}, \mathrm{Si}$,

$176 \mathrm{Sr}$ and $\mathrm{Zn}$ between wood and maize determinations (Figures 1 and 2, and Table 3).

177 Elemental profiles of $P$. truncatus grouped by environment of capture and host availability

178 There were differences in the concentration of some elements in P. truncatus classified by their

179 environment of capture (agriculture, maize or natural). Figures 3 and 4 suggest that agriculture

180 beetles contained more $\mathrm{Al}, \mathrm{B}, \mathrm{Cr}, \mathrm{Fe}, \mathrm{Si}, \mathrm{Ti}$, and $\mathrm{Zn}$, and less $\mathrm{Ni}$ than maize or natural beetles. Whilst

181 maize beetles appeared to have lower levels of $\mathrm{Al}, \mathrm{Ca}, \mathrm{Cu}, \mathrm{Fe}, \mathrm{Mg}, \mathrm{Mn}, \mathrm{P}, \mathrm{S}, \mathrm{Si}, \mathrm{Sr}$ and $\mathrm{Zn}$ than either

182 agriculture or natural beetles, with Ti below DLs. Elemental concentrations in agriculture and natural

183 P. truncatus were similar, although agriculture beetles contained more $\mathrm{Al}, \mathrm{B}, \mathrm{Cr}, \mathrm{Fe}, \mathrm{Si}, \mathrm{Ti}$ and $\mathrm{Zn}$ and

184 less $\mathrm{Ni}$ than natural beetles. These differences were significant for $\mathrm{Al}, \mathrm{Ca}, \mathrm{Cu}, \mathrm{Cr}, \mathrm{Fe}, \mathrm{S}, \mathrm{Si}, \mathrm{Sr}$, $\mathrm{Ti}$ and

$185 \mathrm{Zn}$ in a three-way KW comparison between agriculture, maize and natural groups, but not significant

186 for $\mathrm{B}, \mathrm{Ba}$ and $\mathrm{Ni}$ (Table 4). All pairwise comparisons between elemental determinations of maize

187 against natural beetles, and agriculture versus maize beetles (except Ti) were significantly different

188 at $\mathrm{P}<0.001$ (Table 4). However, only Al, Ba, K, P, Sr and Ti were significantly different in a pairwise

189 comparison between agriculture and natural beetles (Table 4).

When $P$. truncatus were grouped according to those with and without known access to maize, the

192 new field beetle group (all beetles caught in pheromone-baited traps) showed significant differences

193 in the concentrations of most elements with the exception of $\mathrm{B}, \mathrm{Ba}, \mathrm{Ni}$, and $\mathrm{P}$ compared with maize-

194 reared beetles (Table 4). 
195

196

197

\section{Discussion}

This study successfully demonstrates that concentrations of many chemical elements differ between cereals and a natural host of a grain pest, and between insects infesting maize or collected in environments where maize is present and those collected far from environments where only natural hosts are available. Therefore elemental screening of pests can identify potential intrinsic markers of dispersal between cereal infestations and natural reservoirs on alternative hosts. However, the elemental trends in host plants and insects differed, and those able to distinguish between insects reared on maize and others caught in environments without maize, were not the same as those that distinguished between maize and an alternative host. For $P$. truncatus, concentrations of $\mathrm{Al}, \mathrm{Ca}, \mathrm{Cu}$, $\mathrm{Cr}, \mathrm{Fe}, \mathrm{Si}, \mathrm{Sr}, \mathrm{Ti}$ and $\mathrm{Zn}$ differed with their environment of capture, and $\mathrm{Al}, \mathrm{Sr}$ and Ti were also significantly different when all field beetles were compared with those infesting maize suggesting their application as intrinsic markers. In addition, for the more refractory elements like $\mathrm{Si}$, environmental associations with resistant mineral phases (quartz) probably restrict their wider biomarker application.

Mahroof \& Phillips (2012) screened R. dominca and three hosts, acorns (Quercus muhlenbergii (Englelm)), wheat and maize, for 10 elements ( $\mathrm{Ca}, \mathrm{Cu}, \mathrm{Fe}, \mathrm{K}, \mathrm{Mg}, \mathrm{Mn}, \mathrm{Na}, \mathrm{P}, \mathrm{S}$ and $\mathrm{Zn}$ ) and their mean ICP-AES determinations of maize for elements in common with this study are similar: Fe $(20,30$ $\mathrm{mg} / \mathrm{kg}), \mathrm{K}(3600,3800 \mathrm{mg} / \mathrm{kg}), \mathrm{P}(2700,3000 \mathrm{mg} / \mathrm{kg})$ and S $(800,1000 \mathrm{mg} / \mathrm{kg})$ (this study and Mahroof \& Phillips (2012) respectively). They also found more P and $\mathrm{Zn}$ in maize than in a natural host, but trends for Fe and $\mathrm{Mg}$ in maize and natural foods were reversed. They saw no difference in $\mathrm{Ca}$ or $\mathrm{Cu}$ concentrations between maize and acorns, but distinguished wheat because it had more $\mathrm{Ca}$ and $\mathrm{Mn}$ than either acorns or maize. We screened a wider range of elements, and in addition found $\mathrm{Ba}$ and $\mathrm{Sr}$ were above $\mathrm{DL}$ in a candidate alternative host but not maize, and also detected more Al, $\mathrm{Ca}, \mathrm{Cu}, \mathrm{Fe}, \mathrm{Mg}$ and $\mathrm{Si}$, and less $\mathrm{P}$ and $\mathrm{Zn}$ in the alternative host than in maize. 
219 Five elements, Ca, K, Mg, P, S and Zn, were identified as likely markers for the environment of

220 capture or known dietary history in both $P$. truncatus and $R$. dominica, with $\mathrm{Al}, \mathrm{B}, \mathrm{Ba}, \mathrm{Ca}, \mathrm{Cu}, \mathrm{Fe}, \mathrm{K}$,

$221 \mathrm{Mn} \mathrm{S}, \mathrm{Sr}, \mathrm{Zn}$ and Si concentrations differing between maize-reared and field-captured $P$. truncatus

222 suggesting they can distinguish between beetles that complete their life-cycle solely on maize from

223 those that consume natural foods or mixed diets. It would be useful to test this experimentally and

224 develop dispersal models for pests based upon unique suites of elements that vary with their natal

225 hosts, and to investigate temporal changes in the elements present in insects and plants. A limitation

226 of our study was that only one alternative host was profiled for a species which has many potential

227 host plants (Nang'ayo et al., 2002). However, if elemental profiles of insects derive from the

228 geochemistry of their environment we would expect to see chemical differences between those

229 feeding on plants growing in natural environments and those infesting crops grown in soils that

230 undergo regular cultivation and agrochemical regimes. In addition the interpretation of field-

231 captured beetles was limited by lack of successful rearing of $P$. truncatus on S. purpurea, although

232 other studies have also experienced negative or inconsistent results with $P$. truncatus on non-maize

233 hosts that could not be controlled (Detmers et al., 1993; Nang'ayo et al., 2002, Nansen et al., 2004).

234 S. purpurea is an appropriate model for alternative hosts as it is widely distributed in Mexico and a

235 known host of $P$. truncatus in natural vegetation (Calderón-Cortés et al., 2011).

236 A number of studies using different analytical techniques have determined multiple chemical

237 profiles of insects with the aim of tracking dispersal and movement between host plants and field

238 locations. These include Energy Dispersive X-ray Spectrometry for aphids and moths (Bowden et al.,

239 1984; Bowden et al., 1985b; Sherlock et al., 1986), and IPC-AES for cotton boll weevils (Burns et al.,

240 1985) as well as $R$. dominica (Mahroof \& Phillips, 2012). Technique, local geochemistry and the

241 nature of materials tested can all influence the selection of particular elements as intrinsic markers,

242 but multi-elemental screening shows potential for finding appropriate markers for each scenario. In

243 the future, with recent improved detection and sensitivity of techniques, it will be possible to

244 determine profiles for individual insects especially larger species. Also non-destructive methods like 
245 Laser Ablation can allow other analyses such as DNA-sequencing or stable isotope analysis to be

246 completed on a single insect, increasing the data that can inform the origin of each individual. By

247 comparison, a bulk sample as used here may miss differences between individuals, but can give an

248 overall indication of assimilated diet by the population captured.

ICP-AES provides robust evidence for assessing intrinsic markers and identifying consistent trends in

host materials and the herbivores consuming them. These can be tested in controlled field and

laboratory feeding trails, and incorporated into multivariate predictive models in a similar way to the

geospatial isoscape approach applied to stable isotope determinations (West et al., 2010), which can

reveal assimilated and natal diet in holometabolous insects which switch between C3 and C4 plant

hosts (Mahroof \& Phillips, 2007). However, when screening for rare or trace elements which

naturally exist at low concentrations in organisms, the data distributions are frequently left skewed

and rarely conform to normal distributions, hence do not fit the assumptions of parametric

techniques such as Linear Discriminant Analysis and Principal Components Analysis. In this study, as

in many clinical trials and behavioural research, some data were based on small sample sizes or were

imbalanced when a determination was below DLs. We addressed these using non-parametric tests in

an exact inference method (Gibbons JD \& Chakraborti S, 2003). Other chemical screening data of

insect pests show similar data distributions, often with low or unequal replication (Burns et al., 1985;

Peng et al., 2012), and in common with good practice in other studies we ensured consistency of

chemical assays by comparing samples with laboratory standards and our reference materials.

Nevertheless multi-elemental analyses are powerful tools for tracing dispersal of organisms 
270 conservation concern, and for authenticating the origin of high value biological material including

271 foodstuffs and organisms protected under CITIES.

\section{Acknowledgements}

273 We thank Guy Wiltshire (UWS) for ICP-AES determinations, Rick Hodges (University of Greenwich)

274 for $P$. truncatus founder cultures and our Mexican collaborators for their generous support with field

275 work: Miguel Najerra Rincón (CENAPROS, Morelia), Francisco Wong Corral (Universidad de Sonora),

276 Josué Leos Martínez and Adriana Legorreta Millàn, (Universidad de Nuevo Léon) and Dr Mario

277 Ramírez Martínez (Almacenadora Mercader S.A., Guadalajara). This study was funded by NERC New

278 Investigators Scheme Award NER/M/S/2001/00122 to Barbara Tigar. Special thanks go to Roger

279 McLean for support and access to facilities at UWS. We thank the three reviewers for their

280 comments, and suggesting areas for improvement on our manuscript.

281

282

283

284

285

286

287

288

289

290

291

292

293

\section{References}

Borgemeister C, Tchabi A \& Scholz D (1998a) Trees or stores? The origin of migrating Prostephanus

truncatus collected in different ecological habitats in southern Benin. Entomologia Experimentalis et Applicata 87: 285-294.

Borgemeister C, Goergen G, Tchabi A, Awande S, Markham RH \& Scholz D (1998b) Exploitation of a woody host plant and cerambycid-associated volatiles as host-finding cues by the larger grain borer (Coleoptera : Bostrichidae). Annals of the Entomological Society of America 91: 741-747.

Bowden J, Digby P \& Sherlock P (1984) Studies of elemental composition as a biological marker in insects 1 . The influence of soil type and host-plant on elemental composition of Noctua pronuba (L) (Lepidoptera, Noctuidae). Bulletin of Entomological Research 74: 207-225.

Bowden J, Sherlock P \& Digby P (1985a) Studies of elemental composition as a biological marker in insects 3. Comparison of Apterous and Alate cereal aphids, especially Rhopalosiphum padi (L) 
294 (Hemiptera, Aphididae), from oats and wheat, and from oats infected with or free from barley

295 yellow dwarf virus. Bulletin of Entomological Research 75: 477-488.

296 Bowden J, Sherlock P, Digby P, Fox J \& Rhodes J (1985b) Studies of elemental composition as a

297 biological marker in insects 2. The elemental composition of Apterae of Rhopalosiphum padi (L) and

298 Metopolophium dirhodum (Walker) (Hemiptera, Aphididae) from different soils and host plants.

299 Bulletin of Entomological Research 75: 107-120.

300 Burns DW, Parsons ML, Herbaugh LL \& Staten RT (1985) The migrating weevil. A challenge for ICP-

301 AES and chemometrics. Analytical Chemistry 57: 1048A-1052A. doi:10.1021/ac00286a001.

302 Calderón-Cortés N, Quesada M \& Escalera-Vázquez LH (2011) Insects as Stem Engineers: Interactions

303 Mediated by the Twig-Girdler Oncideres albomarginata chamela Enhance Arthropod Diversity. PLoS

304 ONE 6: e19083. doi:10.1371/journal.pone.0019083.

305 Cogburn RR, Burkholder WE \& Williams HJ (1984) Field Tests with the Aggregation Pheromone of the 306 Lesser Grain Borer (Coleoptera: Bostrichidae). Environmental Entomology 13: 162-166.

307 Edde, P. A., \& Phillips TW. (2006) Potential host affinities for the lesser grain borer, Rhyzopertha

308 dominica (F.) (Coleoptera: Bostrichidae): behavioral responses to host odours and pheromones and

309 reproductive ability on non-grain hosts. Entomologia Experimentalis et Applicata. 119: 255-263.

310 Dendy J, Dobie P, Saidi J \& Sherman C (1989) The design of traps for monitoring the presence of

311 Prostephanus truncatus (Horn) (Coleoptera: Bostrichidae) in maize fields. Journal of Stored Products

312 Research 25: 187-191. doi:10.1016/0022-474x(89)90023-4.

313 Detmers HB, Laborius GA, Rudolph D \& Schulz FA (1993) Infestation of wood by the Larger Grain

314 Borer Prostephanus truncatus (Horn) (Coleoptera, Bostrichidae). Vol. 8: Communications of the

315 Deutschen Gesellschaft Fur Allgemeine Und Angewandte Entomologie: Proceedings of the

316 Entomologists Meeting, pp. 803-808. 
317 Dytham C (2011) Choosing and Using Statistics: A Biologist's Guide. 3rd Edition edn. Wiley-Blackwell,

318 Chichester, UK.

319 Engström E, Stenberg A, Senioukh S, Edelbro R, Baxter DC \& Rodushkin I (2004) Multi-elemental

320 characterization of soft biological tissues by inductively coupled plasma-sector field mass

321 spectrometry. Analytica Chimica Acta 521: 123-135.doi:http://dx.doi.org/10.1016/j.aca.2004.06.030.

322 Gal J, Markiewicz-Patkowska J, Hursthouse A \& Tatner P (2008) Metal uptake by woodlice in urban

323 soils. Ecotoxicology and environmental safety 69: 139-149. doi:10.1016/j.ecoenv.2007.01.002.

324 Gibbons JD \& Chakraborti S (2003). Nonparametric Statistical Inference. $4^{\text {th }}$ edn CRC Press, Boca

325 Raton, Florida.

326 Forcella F (1982) Why twig-girdling beetles girdle twigs. Naturwissenschaften 69: 398-400.

327 Gal J, Markiewicz-Patkowska J, Hursthouse A \& Tatner P (2008) Metal uptake by woodlice in urban

328 soils. Ecotoxicology and environmental safety 69: 139-149. doi:10.1016/j.ecoenv.2007.01.002.

329 Haines CP (2000) IPM for food storage in developing countries: 20th Century aspirations for the 21st

330 Century. Crop Protection 19: 825-830. doi:10.1016/s0261-2194(00)00110-1.

331 Helbig J, Laborius GA \& Schulz FA (1992) Investigations on the distance of trapping activity of the

332 synthetic pheromone Trunc-call (1+2) of Prostephanus truncatus (Horn) (Col, Bostrichidae) on its

333 predator Teretriosoma nigrescens Lewis (Col, Histeridae). Journal of Applied Entomology-Zeitschrift

334 Fur Angewandte Entomologie 113: 425-429.

335 Hodges RJ, Cork A \& Hall DR (1984) Aggregation pheromones for monitoring the greater grain borer

336 Prostephanus truncatus, British Crop Protection Conference, Pests and Diseases, Brighton, UK, pp

$337 \quad 255-259$.

338 Hodges RJ, Dunstan WR, Magazini I \& Golob P (1983) An outbreak of Prostephanus truncatus (Horn)

339 (Coleoptera, Bostrichidae) in East Africa. Protection Ecology 5: 183-194. 
340 Hodges RJ, Meik J \& Denton H (1985) Infestation of dried cassava (Manihot esculenta Crantz) by

341 Prostephanus truncatus (Horn) (Coleoptera: Bostrichidae). Journal of Stored Products Research 21:

342 73-77. doi:10.1016/0022-474x(85)90024-4.

343 Jia F, Toews MD, Campbell JF \& Ramaswamy SB (2008) Survival and reproduction of lesser grain

344 borer, Rhyzopertha dominica (F.) (Coleoptera: Bostrichidae) on flora associated with native habitats

345 in Kansas. Journal of Stored Products Research 44: 366-372. doi:10.1016/j.jspr.2008.06.001.

346 Kelly S, Heaton K \& Hoogewerff J (2005) Tracing the geographical origin of food: The application of

347 multi-element and multi-isotope analysis. Trends in Food Science \& Technology 16: 555-567.

348 doi:http://dx.doi.org/10.1016/j.tifs.2005.08.008.

349 Liu L-Y, Schoenitzer K \& Yang J-T (2008) A review of the literature on the life history of Bostrichidae

350 (Coleoptera). Mitteilungen Muenchener Entomologischen Gesellschaft 98: 91-97.

351 Mahroof RM, Edde PA, Robertson B, Puckette JA \& Phillips TW (2010) Dispersal of Rhyzopertha

352 dominica (Coleoptera: Bostrichidae) in Different Habitats. Environmental Entomology 39: 930-938.

353 doi:10.1603/EN09243.

354 R. M. Mahroof \& T. W. Phillips (2007). Stable isotopes as markers to investigate host use by

355 Rhyzopertha dominica. Entomologia Experimentalis et Applicata. 125: 205-213.

356 Mahroof RM \& Phillips TW (2012) Use of macro and trace elements as biological markers in the

357 lesser grain borer, Rhyzopertha dominica (F.) (Coleoptera:Bostrichidae). Journal of Stored Products

358 Research 48: 126-131. doi:10.1016/j.jspr.2011.10.008.

359 Munro JW (1940) DSIR report on a survey of the infestation of grain. B Insects: HMSO, London, UK, 360 p. 54. 
361 Nang'ayo FLO, Hill MG \& Wright DJ (2002) Potential hosts of Prostephanus truncatus (Coleoptera:

362 Bostrichidae) among native and agroforestry trees in Kenya. Bulletin of Entomological Research 92:

363 499-506. doi:10.1079/ber2002202.

364 Nansen C \& Meikle WG (2003) Use of pheromone-baited trap catches as indicators of occurrence of 365 potential hosts of Prostephanus truncatus (Horn) (Coleoptera: Bostrichidae) in a forest in southern 366 Benin. Advances in Stored Product Protection. 8th International Working Conference on Stored 367 Product Protection (IWCSPP), pp 71-77.

368 Nansen C, Meikle WG \& Korie S (2002) Spatial analysis of Prostephanus truncatus (Bostrichidae:

369 Coleoptera) flight activity near maize stores and in different forest types in southern Benin, West

370 Africa. Annals of the Entomological Society of America 95: 66-74.

371 Nansen C, Meikle WG, Tigar B, Harding S \& Tchabi A (2004) Nonagricultural hosts of Prostephanus

372 truncatus (Coleoptera: Bostrichidae) in a west African forest. Annals of the Entomological Society of

373 America 97: 481-491. doi:Doi 10.1603/0013-8746(2004)097[0481:Nhoptc]2.0.Co;2.

374 Peng Q, Tang QY, Wu JL, Miao QL \& Cheng JA (2012) Determining the geographic origin of the brown 375 planthopper, Nilaparvata lugens, using trace element content. Insect Science 19: 21-29.

376 doi:10.1111/j.1744-7917.2011.01438.x.

377 Ramírez Martínez M, De Alba Avila A \& Ramirez Zurbia R (1994) Discovery of the Larger Grain Borer 378 in a tropical deciduous forest in Mexico. Journal of Applied Entomology 118: 354-360.

379 Rees DP, Rodriguez R, R. \& Herrera R FJ (1990) Observations on the ecology of Teretriosoma 380 nigrescens Lewis (Col.: Histeridae) and its prey Prostephanus truncatus (Horn)(Col.: Bostrichidae) in 381 the Yucatan peninsula, Mexico. Tropical Science 30: 153-165. 
382 Sherlock P, Bowden J \& Digby P (1985) Studies of elemental composition as a biological marker in

383 insects 4. The influence of soil type and host-plant on elemental composition of Agrotis segetum

384 (Denis and Schiffermuller) (Lepidoptera, Noctuidae). Bulletin of Entomological Research 75: 675-687.

385 Sherlock P, Bowden J \& Digby P (1986) Studies of elemental composition as a biological marker in

386 insects 5. The elemental composition of Rhopalosiphum padi (L) (Hemiptera, Aphididae) from Prunus

387 padus at different locatilites. Bulletin of Entomological Research 76: 621-632.

388 Systat Software Inc. (2009) SYSTAT 13 Exact tests-1. Systat Software Inc., Chicago, USA.

389 Tigar B \& Waldron S (2003) Using new tools to track the larger grain borer, Prostephanus truncatus

390 (Horn) (Coleoptera: Bostrichidae). Advances in Stored Product Protection. 8th International Working

391 Conference on Stored Product Protection (IWCSPP), pp396-401.

392 Tigar BJ, Osborne PE, Key GE, Flores ME \& Vazquez M (1994) Distribution and Abundance of

393 Prostephanus truncatus (Coleoptera, Bostrichidae) and Its Predator Teretriosoma nigrescens

394 (Coleoptera, Histeridae) in Mexico. Bulletin of Entomological Research 84: 555-565.

395 West, J.B., Bowen, G.J., Dawson, T.E., Tu, K.P. (Eds.)( 2010) Isoscapes: Understanding movement, 396 pattern, and process on Earth through isotope mapping. Springer Netherlands, DOI 10.1007/978-90-

397 481-3354-3.

398 Williams HJ, Silverstein RM, Burkholder WE \& Khorramshahi A (1981) Dominicalure 1 and 2:

399 Components of aggregation pheromone from male lesser grain borer Rhyzopertha dominica (F.)

400 (Coleoptera: Bostrichidae), Journal of Chemical Ecology 7: 759-780.

401 
402 Table 1. Groups used to classify P. truncatus according to the characteristics of their collection sites

403 and access to maize $(n=$ number of determinations, each consisting of bulk samples of 10 beetles

404 per determination).

\begin{tabular}{|l|l|}
\hline Group for elemental comparison & Definition and collection-site characteristics \\
\hline Maize $(n=32)$ & Reared through two generations from egg to adult on maize \\
\hline Agriculture $(n=10)$ & $\begin{array}{l}\text { Field-caught in pheromone-baited traps in open arable areas } \\
\text { production, where maize was growing and approaching } \\
\text { maturity }\end{array}$ \\
\hline Natural $(n=8)$ & $\begin{array}{l}\text { Field-caught in pheromone-baited traps in areas of natural or } \\
\text { semi-natural vegetation including dense deciduous and } \\
\text { coniferous woodland, and semi-arid rangeland with sparse } \\
\text { trees and shrubs. All at least } 12 \text { km from nearest dwellings, } \\
\text { agriculture or maize stores }\end{array}$ \\
\hline Field $n=(18)$ & $\begin{array}{l}\text { Combination of all field-caught in pheromone-baited traps } \\
\text { (agriculture plus natural as defined above) }\end{array}$ \\
\hline
\end{tabular}

405 
406 Table 2. ICP-AES Detection Limits (DL) for elements most likely to occur at low concentrations. These

407 were determined from the bulk reference samples of $P$. truncatus and maize (and incorporating 408 material from all sources to be analysed) and extrapolated for wood from maize.

409

\begin{tabular}{|c|c|c|}
\hline \multirow{2}{*}{ Element } & \multicolumn{2}{|c|}{ Detection Limit (mg/kg) } \\
\hline $\mathrm{Al}$ & 6 & 2.4 \\
\hline $\mathrm{Ba}$ & 0.2 & 0.06 \\
\hline $\mathrm{Cu}$ & 0.3 & 0.1 \\
\hline $\mathrm{Cr}$ & 0.8 & 0.4 \\
\hline $\mathrm{Fe}$ & 3 & 1.1 \\
\hline $\mathrm{Mg}$ & 1 & 0.4 \\
\hline $\mathrm{Mn}$ & 0.3 & 0.1 \\
\hline $\mathrm{Ni}$ & 2.8 & 1.1 \\
\hline $\mathrm{Sr}$ & 0.03 & 0.01 \\
\hline $\mathrm{Ti}$ & 0.2 & 0.06 \\
\hline $\mathrm{Zn}$ & 3.5 & 1.3 \\
\hline
\end{tabular}


411 Table 3. Results of pairwise comparisons between the elemental loadings of maize and wood, for

412 elements above DLs in both plant hosts. All comparisons assume $1 \mathrm{df}$. (Results in bold were

413 significantly different).

\begin{tabular}{|c|c|c|c|}
\hline \multirow{2}{*}{ Element } & $\begin{array}{c}|c| \\
\text { Mann-Whitney } \\
\text { U statistic }\end{array}$ & $\begin{array}{c}\text { KW statistic } \\
\text { (X) }\end{array}$ & p-value \\
\hline $\mathrm{Al}$ & 2 & 8.81 & $\mathbf{0 . 0 0 3}$ \\
\hline $\mathrm{B}$ & 2 & 11.75 & $\mathbf{0 . 0 0 1}$ \\
\hline $\mathrm{Ba}$ & 0 & 3.82 & 0.051 \\
\hline $\mathrm{Ca}$ & 0 & 12.03 & $\mathbf{0 . 0 0 1}$ \\
\hline $\mathrm{Cu}$ & 5 & 11.96 & $\mathbf{0 . 0 0 1}$ \\
\hline $\mathrm{Fe}$ & 16 & 6.49 & $\mathbf{0 . 0 1 1}$ \\
\hline $\mathrm{K}$ & 44 & 0.85 & 0.356 \\
\hline $\mathrm{Mg}$ & 13 & 7.37 & $\mathbf{0 . 0 0 7}$ \\
\hline $\mathrm{Mn}$ & 47 & 0.57 & 0.449 \\
\hline $\mathrm{P}$ & 120 & 12.02 & $\mathbf{0 . 0 0 1}$ \\
\hline $\mathrm{S}$ & 74 & 0.65 & 0.419 \\
\hline $\mathrm{Si}$ & 6 & 9.78 & $\mathbf{0 . 0 0 1}$ \\
\hline $\mathrm{Zn}$ & 120 & 12.02 & $\mathbf{0 . 0 0 1}$ \\
\hline
\end{tabular}

414 
415 Table 4. Kruskal Wallis three-way comparison of beetles by agriculture, maize and natural groups,

416 with post hoc Dwass-Steel-Chritchlow-Fligner pairwise comparisons between groups and Kruskal

417 Wallis two-way comparison all field-caught and maize-reared beetles. (V and Zr were below DLs.)

418 (Significant differences are in bold.)

\begin{tabular}{|c|c|c|c|c|c|c|c|}
\hline \multirow[t]{2}{*}{ Element } & \multicolumn{2}{|c|}{$\begin{array}{l}\text { Three-way comparison } \\
\text { agriculture* maize*natural }\end{array}$} & \multicolumn{3}{|c|}{$\begin{array}{l}\mathrm{p} \text {-value for Dwass-Steel-Chritchlow- } \\
\text { Fligner Test for Pairwise Comparisons }\end{array}$} & \multicolumn{2}{|c|}{$\begin{array}{l}\text { Two-way } \\
\text { comparison } \\
\text { field*maize }\end{array}$} \\
\hline & $\begin{array}{c}\text { Kruskal- } \\
\text { Wallis Test } \\
\text { Statistic }\end{array}$ & $p$-value & $\begin{array}{l}\text { agriculture } \\
* \text { maize }\end{array}$ & $\begin{array}{l}\text { agriculture } \\
* \text { natural }\end{array}$ & $\begin{array}{l}\text { maize } \\
* \text { natural }\end{array}$ & $\begin{array}{l}\text { Kruskal- } \\
\text { Wallis } \\
\text { Test } \\
\text { Statistic }\end{array}$ & $\begin{array}{c}\mathrm{p}- \\
\text { value }\end{array}$ \\
\hline $\mathrm{Al}$ & 27.09 & $<0.001$ & $<0.001$ & 0.007 & $<0.001$ & 27.09 & $<0.001$ \\
\hline$B$ & 1.35 & 0.51 & $<0.001$ & 0.83 & $<0.001$ & 0.72 & 0.4 \\
\hline $\mathrm{Ba}$ & 0.37 & 0.83 & $<0.001$ & 0.003 & $<0.001$ & 0.34 & 0.56 \\
\hline $\mathrm{Ca}$ & 27.59 & $<0.001$ & $<0.001$ & 0.97 & $<0.001$ & 26.77 & $<0.001$ \\
\hline $\mathrm{Cr}$ & 6.27 & 0.044 & $<0.001$ & 0.54 & $<0.001$ & 5.6 & 0.02 \\
\hline $\mathrm{Cu}$ & 14.41 & 0.001 & $<0.001$ & 0.13 & $<0.001$ & 14.35 & $<0.001$ \\
\hline $\mathrm{Fe}$ & 18.69 & $<0.001$ & $<0.001$ & 0.76 & $<0.001$ & 17.68 & $<0.001$ \\
\hline $\mathrm{K}$ & 4.55 & 0.10 & $<0.001$ & 0.004 & $<0.001$ & 4.43 & 0.04 \\
\hline $\mathrm{Mg}$ & 4.66 & 0.10 & $<0.001$ & 0.81 & $<0.001$ & 4.47 & 0.03 \\
\hline $\mathrm{Mn}$ & 5.26 & 0.07 & $<0.001$ & 0.56 & $<0.001$ & 3.56 & 0.06 \\
\hline $\mathrm{Ni}$ & 1.12 & 0.52 & $<0.001$ & 0.08 & $<0.001$ & 1.12 & 0.29 \\
\hline$P$ & 16.93 & $<0.001$ & $<0.001$ & $<0.001$ & $<0.001$ & 1.77 & 0.18 \\
\hline$S$ & 1.94 & 0.38 & $<0.001$ & 0.86 & $<0.001$ & 16.93 & $<0.001$ \\
\hline $\mathrm{Si}$ & 9.95 & 0.007 & $<0.001$ & 0.78 & $<0.001$ & 9.69 & 0.002 \\
\hline $\mathrm{Sr}$ & 16.56 & $<0.001$ & $<0.001$ & $<0.001$ & $<0.001$ & 15.51 & $<0.001$ \\
\hline $\mathrm{Ti}$ & 18.36 & $<0.001$ & 0.90 & $<0.001$ & $<0.001$ & 17.86 & $<0.001$ \\
\hline $\mathrm{Zn}$ & 12.77 & 0.004 & $<0.001$ & 0.43 & $<0.001$ & 10.6 & 0.001 \\
\hline
\end{tabular}

419 


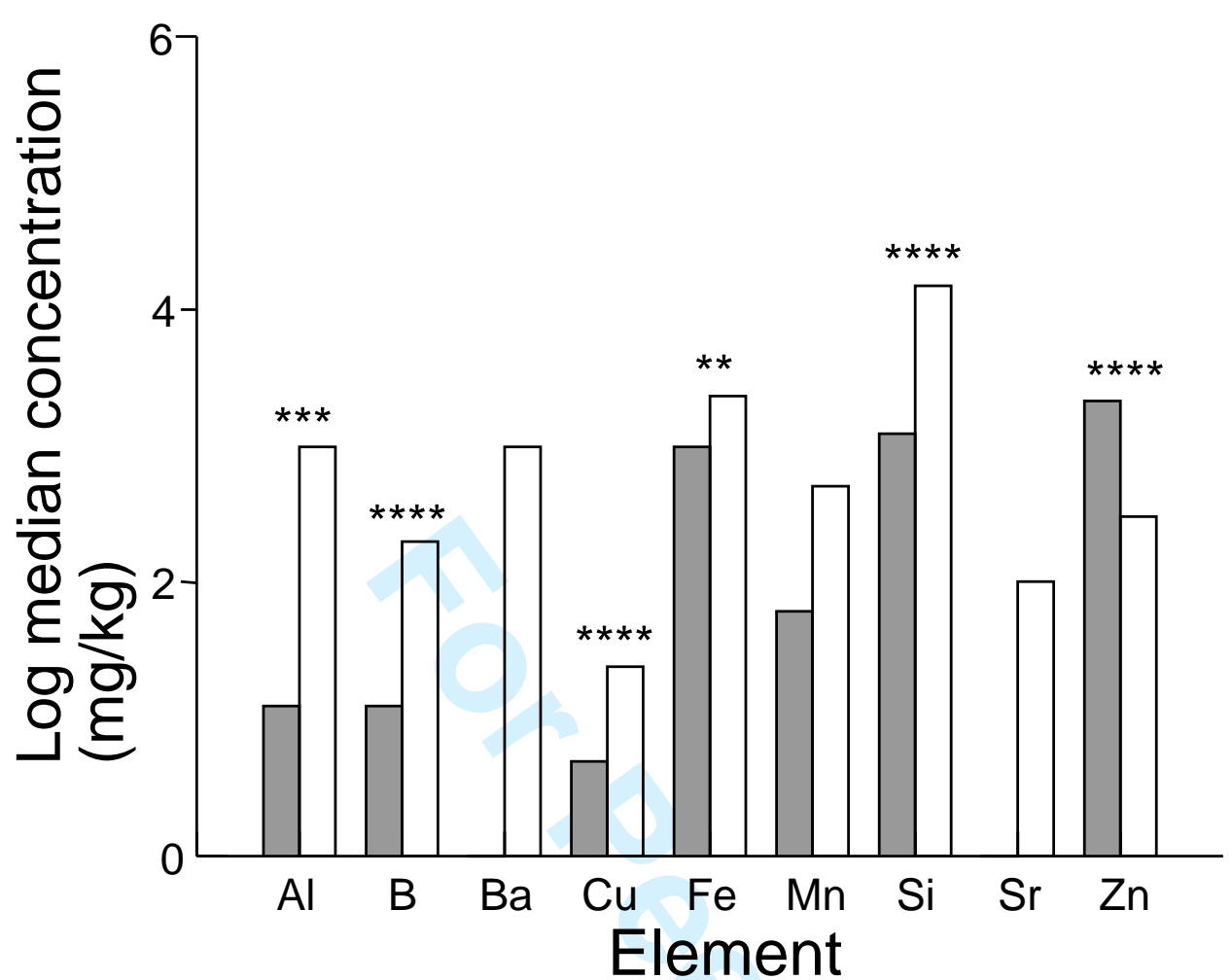




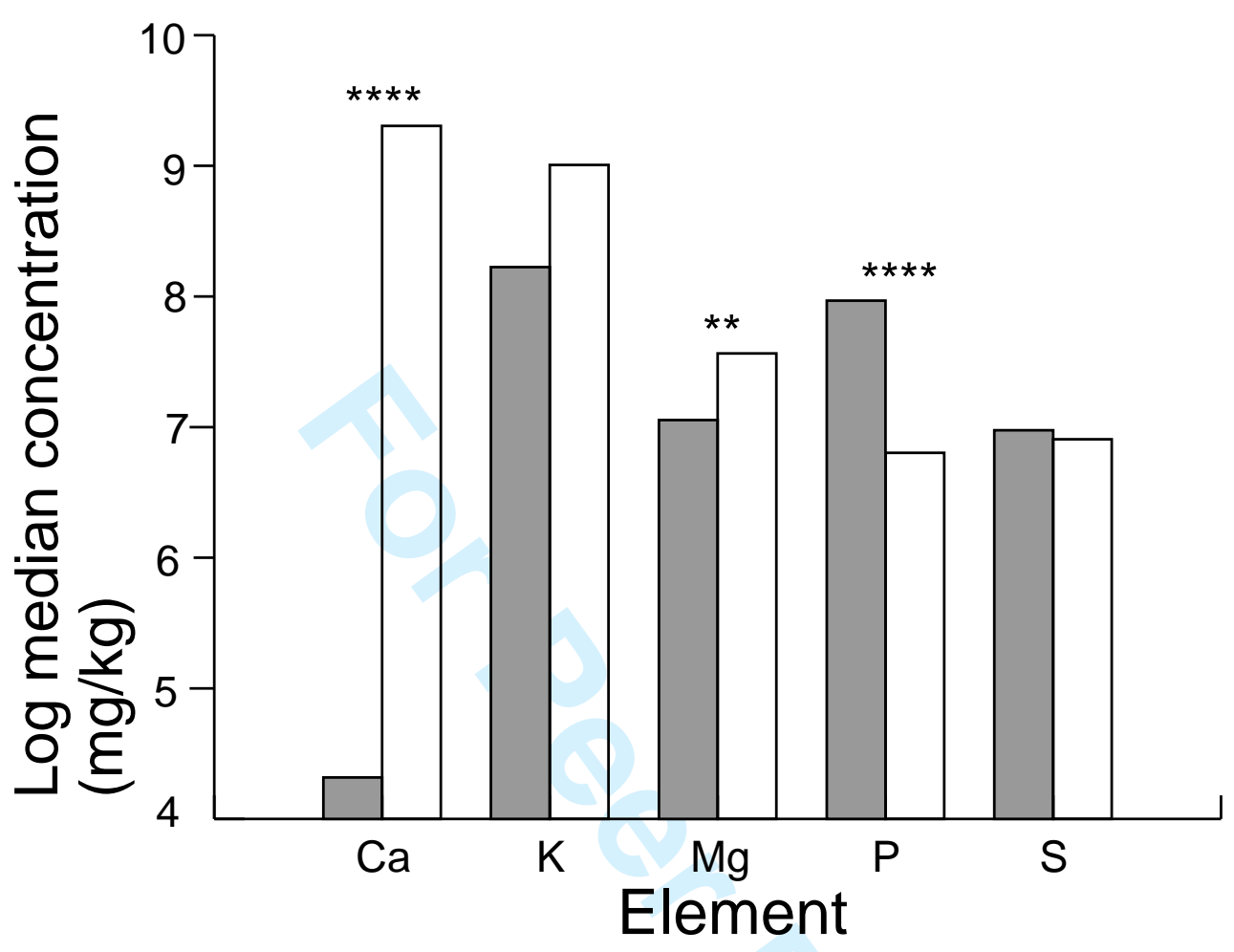




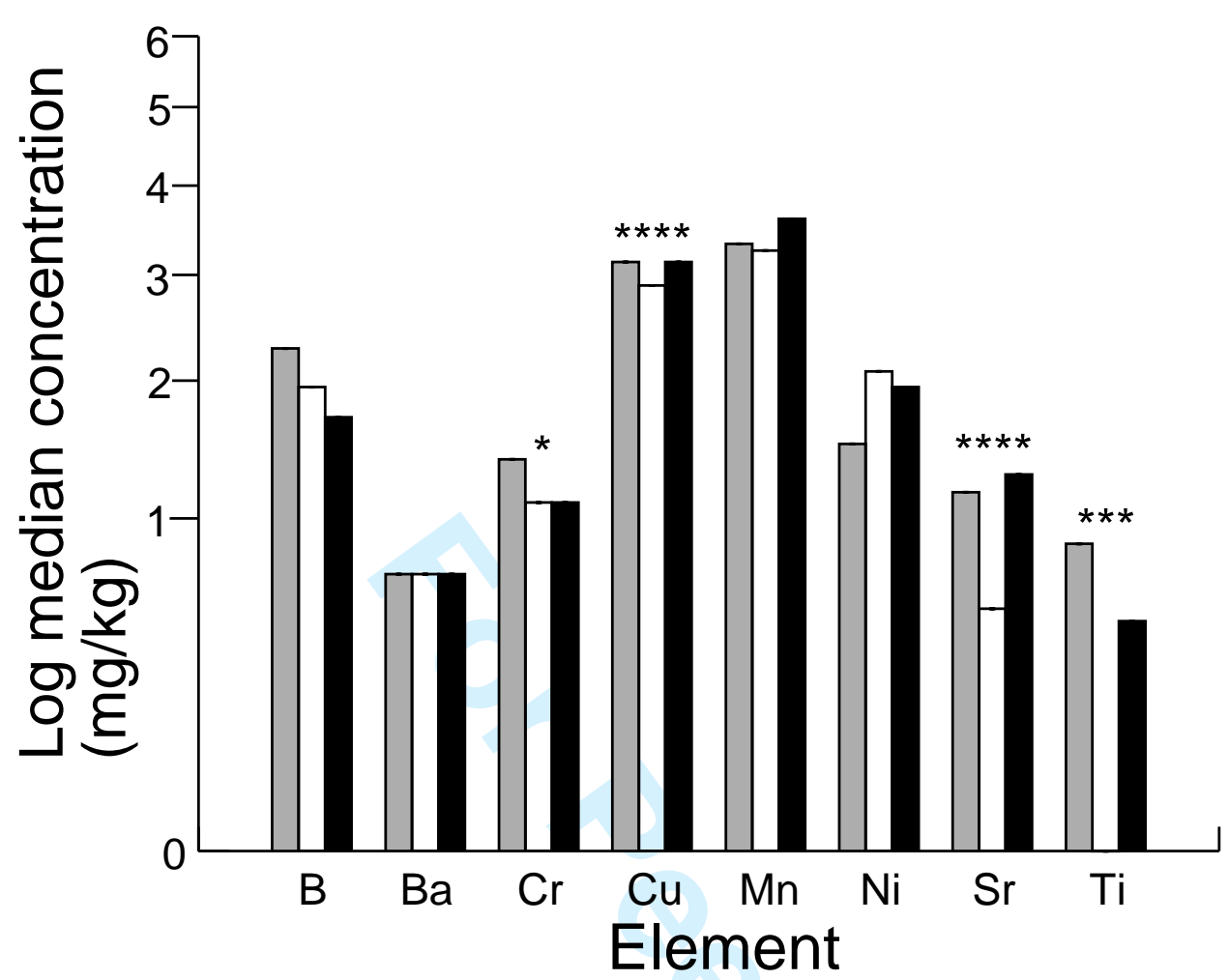




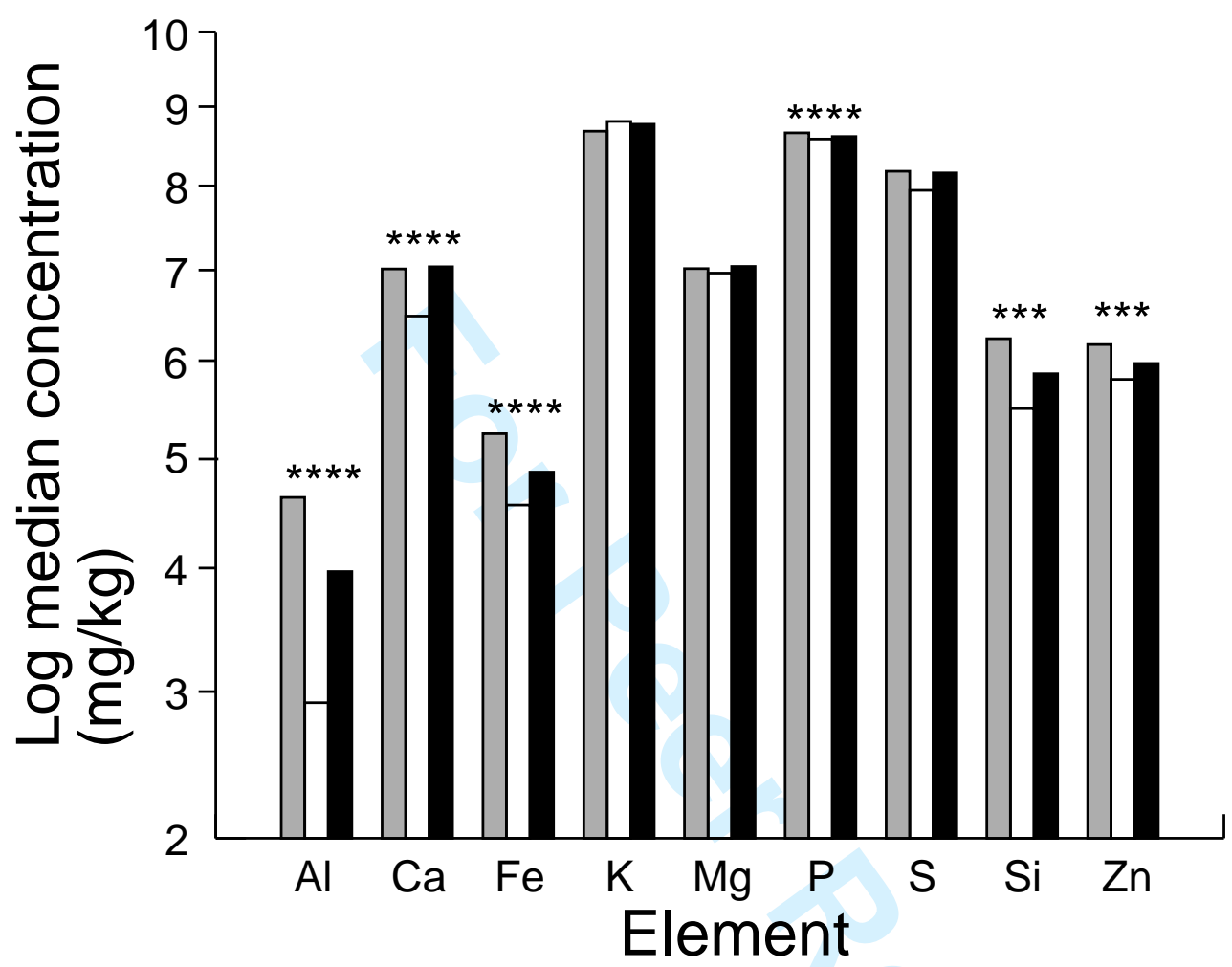

